академик Љубомир Зуковић Академија наука и умјетности Републике Српске, Бања Лука

https://doi.org/10.18485/ai_filip_visnjic.2018.2 821.163.41.09-13:398 Вишњић Ф. 821.163.41.09-13:398 Караџић В. С.

\title{
ЈУБИЛЕЈ ФИЛИПА ВИШЊИЋА
}

Поводом двестапедесетогодишњице од рођења Филипа Вишњића, аутор се бави песмама које је Филип Вишњић певао уз гусле, а Вук Караџић их од њега бележио. Аутор најпре пажњу посвећује песмама које, према Вуковој подели, припадају кругу песама средњих и старијих времена. Предмет интересовања аутора у другом делу рада су песме о Првом српском устанку, које је Вишњић сам спевао, али средствима, и на начин, да их је колектив одмах прихватио као своје.

Кључне речи: Вук Стефановић Караџић, Филип Вишњић, Први српски устанак.

Од бројних послова које је у свом радном веку започео и обављао, а они су и значајни и бројни, Вуку је најдражи посао био бележење и сакупљање народних умотворина, посебно народних песама. Међу њима, опет, посебно јуначких, како их је он сам називао, највероватније, како би избегао употребу страног израза епских. Тај је посао трајао пуних педесет година; пола столећа, дакле. У том дугом низу година постоји, опет, једна година, која се, по значају и лепоти, забележених баш тих песама до којих му је највише и било стало, може изједначити са свим преосталим годинама заједно. То је 1815. година.

То је, опет, имајући на уму значај и лепоту записаних песама, не само непоновљива него, слободно се 
може казати, чудесна година. Више околности је томе допринело. У првом реду, то је био Вуков повратак из Беча у Срем, међу српски народ и лична посвећеност проналажењу певача и записивању народних песама. А певаче је проналазио, пре свега, међу бројним избеглицама из Србије, који су, након пропасти Првог српског устанка, просто били запљуснули данашњу Војводину. Друго, Вук је тачно и на време схватио то колика и каква може бити улога појединца од кога се песма записује, па било да је он пева, или само казује. И, наравно, треће и најважније, срећна околност да су се баш ту и баш те године задесила двојица његових најбољих певача, Тешан Подруговић и Филип Вишњић. Први пореклом Херцеговац, хајдук и истакнути ратник из Првог српског устанка. Други, Семберац, који је, такође, али с песмом и гуслама, упознао истакнуте устаничке вође и учествовао у збивањима на дринском ратишту. Понекад, као у бици за Лозницу, из непосредне близине. Готово би се могло казати - као њен учесник.

Тих дана Вук се срео и са неким својим најпознатијим слепим певачицама, али и са својим оцем Стефаном, који је, у међувремену, такође био ослепио. И од њих је забележио више изузетно лепих песама. Вук је, очигледно, на таласу оног првог, биће и најснажнијег, сакупљачког замаха и понесености. Млад је, тек му је 28 година, а пристигле су и похвале за Малу простонародну славеносербску пјеснарицy, па му се посао кога се прихватио милио.

У бележници је растао број народних песама, а искуство се нагло, и то из прве руке, богати новим сазнањима о њиховом настајању и животу у усменом преношењу. Она, пак, раније стечена сазнања и запажања добијају свежу потврду. Беру се песме, али се беру и нова сазнања о њиховом настајању и опстајању у народном памћењу. Вук је сад заинтересован и усме- 
рен на све оно о чему народ прости пева, приповеда и умује. Он се определио и јасно усмерио.

Подруговић је, превасходно, љубитељ јуначке народне песме који зналачки бира шта ће од онога што је народ створио слушати и памтити. Он то лепо и по реду, са разумевањем, казује, отклањајући замуцкивања претходника којих је, ван сваке сумње, било... Дакле, он је оно што се означава речју рапсод. Вишњић је то такође, али и знатно више од тога. Он, уз помоћ стеченог епског песничког образовања, уме да састави и нову песму о савременим догађајима и јунацима. Јер, уз стечено знање и искуство о томе како се гради епска песма, он поседује и оно, прилично ретко, али зато и најважније: поседује смисао и дар за тај посао, како рече Вук мислећи на стварање нове песме која, већ на почетку, поседује врлине које ће јој обезбедити да се прими и траје у колективном памћењу и усменом преношењу. Вишњић је, према томе и рапсод, али и - аед.

Ето, то су, дакле, биле те повољне околности које су помогле Вуку да тако на самом почетку снажно замахне крилима и да посао којим се пола столећа бавио величанствено заврши.

3бог двестапедесетогодишњице од рођења Филипа Вишњића која пада управо ове године, пажњу ћу усмерити управо на песме које је Вук од њега забележио, а Вишњић их је, за разлику од Подруговића који је песме казивао, певао уз гусле; онако како је целог живота радио од када је, као рано ослепело чељаде, том вештином овладао и од ње живео. Изнећу, најпре, неколико опаски о песмама које је он певао, мање-више, као рапсод, а припадају, према Вуковој подели, кругу песмама средњих и старијих времена. Онда бих се нешто дуже задржао на песмама о Првом српском устанку, које је Вишњић сам спевао, али средствима, и на начин, да их је колектив одмах прихватио као своје. 
Прва песма из круга епског наслеђа, „Свети Сава“, сасвим се незнатно разликује од варијанте која јој у збирци претходи, а Вук ју је записао од слепе Степаније. Лично бих у Вишњићевој варијанти истакао завршне стихове којима господа хришћанска благосиља Немањиће, а посебно оне којим им честита, прво, што су стекли и имали седам кула блага, и, опет посебно, што су умели управити благом. У њиховом случају то значи: нису га потрошили на ратна средства и опрему, на шта се државно и народно богатство и данас највише троши, већ на духовне и културне вредности, за шта се, нажалост, и данас најмање издваја. Вредности које најдуже трају и најблаготворније делују. Наравно, све то у духу свога времена, али, ипак, за оно што ће служити народу у целини, па, на крају, и посебно, оном друштвеном слоју коме је помоћ најнужнија, коме припада и сам певач. Дакле, све градећи по калу калдрме, али и дијелећи кљасту и слијепу. Истичући те ствари, Вишњић хоће да каже да је цео српски народ наследник Немањиног блага, али и то да право на део тог блага припада и њему самом. Слично ће поступити и Марко Краљевић када буде „свијет мијењао“. Један ћемер жутијех дуката намењен је, такође, „кљасту и слијепу: нек слијепи по свијету ходе, нек пјевају и спомињу Марка“. Стихови који делују готово као потпис аутора.

Кад је у питању песма „Свети Сава и Хасан-паша“, истакао бих две ствари које ценим као лични Вишњићев допринос у њој. Прво, она представља усамљен пример народне песме у којој се пророчанско значење сна не остварује, него управо побеђује мисао која најчешће прати његово казивање и тумачење у народним песма, а које гласи: сан је лажа, а Бог је истина! Лако се досетити и зашто се то у овој песми десило. Па зато што се у конкретном случају пророчкој снази сна, која у епским 
народним песмама - упркос наведеној мисли да је сан лажа - готово редовно тријумфује, која је, такорећи, неприкосновена, својим моћима супротставио највећи српски светац - Свети Сава. А изгледало је да је и овде пророчанској моћи сна све ишло на руку. Уснило га је ђаче самоуче, и то „у суботу уочи неђеље“, и значење његово протумачио главом игуман манастира. Уместо сну, све је то увеличало снагу и моћ Светоме Сави.

Друга појединост у овој песми која заслужује да се истакне, и која је такође помало необична, рекао бих на овом месту чак и неочекивана је следећа: - док ђаче самоуче под свежим утиском злокобних слика и призора свога сна Миљешевци на капији цркви грозне сузе лије, игуман га пита за разлог, покушавајући да се њему и сам досети: - „Ил' је тебе књига омрзнула? Или ти је на ум пала мајка? Ил' се, синко, мислиш оженити?“. Нагађа стари игум, па онда наставља: - Ако је књига разлог цвиљењу и сузама, предлаже му, уз љутиту клетву, да је остави. Ако је томе, пак, разлог што му је „на ум пала мајка“, клетва је, уз очигледан прекор, још жешћа, „Иди мајци ти је не виђео!“

Ако је, пак, толиким сузама и цвиљењу „прије зоре и јаркога сунца“ разлог момкова жеља да се ожени, игуман му то не само одобрава, него је, уз благослов, спреман и да га још дарује:

„Жен’ се, синко, у добри час било!

И ја ћу ти ашлук поклонити, и благослов на теб' оставити:

еда Бог да, лијеп пород имо: двије шћери и четири сина!“

Да је овог игумана послати кроз наша запарложена села, пуна крезубих нежења да овим благословом те- 
лали. Питање је само: Би ли га имао ко чути и разумети? Бојим се да би најмање било оних који би га послушали.

Ђаче је, наравно, свој „чудан санак, а у чудан данак“ могло игуману казати и без ових игуманових питања, претпоставки и коментара који су уследили, али је певачу, очигледно, било стало до њихове поруке, која је и тада имала, а данас, поготову, има свој пуни смисао. Овоме игуману манастир није била ни једина, а, изгледа, не главна брига. У међувремену, брига, која се овде тек назире, добила је чак претеће размере. Након ове игуманове, готово узгредне, али врло битне поруке, песма је, како рекох, усмерена на истицање потребе вере у снагу Бога и његових угодника, што је, уосталом, заједничка карактеристика свих Вишњићевих песама. Пред том снагом и пророчка моћ сна, иначе, имајући на уму целину наше народне епике, готово неприкосновена морала је да устукне.

Има, заиста, неке и симболике и логике у томе што је најлепшу песму о смрти Марка Краљевића Вуку отпевао управо Филип Вишњић. Као да су и јунак и певач пожелели да ослободе и припреме епску позорницу за нове догађаје и нове српске јунаке, устанике и ослободиоце, људе спремне и способне „сваки своје да покаје старе“. Да васкрсну изгубљену слободу и достојанство народно. Доста се и Марко око тога мучио, злопатио и мегдана делио.

Вероватно није случајно ни то што је Вук реч слобода употребио тек у поднаслову своје четврте књиге Српских јуначких пјесама, а још мање је случајно што се ова реч помиње тек у песмама из те књиге. И то први пут у песми митрополита Петра Првог Петровића Његоша „Бој Црногораца с Махмут-пашом“ у стиху који гласи: ради вјере и слободе драге, а потом и два пута у Вишњићевим песама о Првом српском устанку. У његовој песми „Бој на Салашу“, непосредно пред судар са 
бројно вишеструко надмоћнијим противником, Стојан Чупић саветује својим борцима: „Напијте се поцерске ракије зарад срца и зарад слободе“. Док у песми „Лазар Мутап и Арапин“, Мутап за учињену услугу Вожду, тражи као награду „слободу јуначку, да ми нико судити не може осим Бога и тебе једнога“. Као да је ова реч била просто протерана из српскога језика. Умрла као и оно што је означавала у свест и грудима Срба. Да се на овом месту присетимо Његошевих речи: бјеху мушка прса охладюела, а у ғима умрла слобода. Зато су се, у страху и малодушном самопорицању, била затурила, готово сасвим изгубила лепа српска имена Слободан и Слободанка. Да се не би поробљивач узнемиравао и подозревао.

Иначе, Вишњићева варијанта песме „Смрт Марка Краљевића“ нуди јасну свест о томе да је, истина, том типу епских јунака након неколико векова његовог неприкосновеног владања, дошао крај, али, у исти мах, и свест да тај епохални изум српске народне епике, по много чему јединствен у свету, не може подлећи у сукобу са неким противником од овога света. Било би то у нескладу са свим оним чиме је песма његов епски лик снабдела и особила. Не би се слагало с његовом богатом епском биографијом.

Марков се живот гаси на необичан начин, нагло и без самртног ропца - доље леже, горе не устаде; али, искључиво, вољом Бога, песник каже: старога крвника. Што ће рећи да их је, уз све оно чиме их је даровао и наградио, Бог људе, ипак, створио смртним. А човекова исконска жеља за животом зазвучаће не само снажније него, истовремено, и са једном благом дозом хумора, ако то на крају свог необично дугог века каже управо Марко док се растаје са животом и умира шта је све видео и доживео у њему: 
„Лажив св’јете, мој лијепи цв’јете!

Л’јеп ти бјеше, ја за мало ходах,

Та за мало, три стоти' година!

Земан дође да св’јетом пром’јеним“.

У сваком случају, песник је водио рачуна о томе да се приказом Маркове кончине ничим видно не наруши јединство народног епа о њему, да све буде и складу с клетвом и благословом којим су га у песми Старца Рашка „Урош и Мрњавчевићи“ дочекали отац Вукашин и кум Урош. И по томе се види да је Вишњић познавао целину народног епа о Марку Краљевићу. Зато ова песма и делује као логичан крај тог епа.

Песма „Бајо Пивљанин и бег Љубовић“ је једна савршено испричана прича о двобоју између бега и познатог харамбаше хајдучког, као и обострано убедљивој мотивацији зашто је до њега морало да дође. Да се није одиграо у сенци нечасне подвале и још горе побратимске издаје, једва да би сам двобој и заслуживао јуначку песму. Можда још једино по дубоко људском Бајовом кајању и признању грешке учињене у младости, као и беговом упорном настојању да га понизи и осрамоти, па тек онда, можда, и пристане на помирење. Песма је пропраћена двема Вуковим напоменама. Она уз стих узми больег, остави горега односи се на мач, а гласи: „По правилу би боље било: узми бољи, а остави гори, али сам оставио као што је пјевао слијепац Филип“. И добро је што је, и у овом случају, граматичка правилност узмакнула пред песничком логиком. Обрнуто, ипак, не би „боље било“. Стих који би био по правилу, како мисли Вук, звучао би нешто тврђе, готово као заповест. Песма, уз то, воли да ствари онеобичава.

Као слепац и неуморни путник од сабора до сабора, од богомоље до богомоље, доспевајући из своје Семберије чак до Скадра и Пљеваља, Вишњић је не- 
сумњиво знао још народних песама о догађајима и јунацима старијих и средњих времена, а што их се више није нашло у Вуковој бележници, биће да је томе главни разлог тај што је скупљач, у том тренутку, предност дао песмама о Првом српском устанку, које са друге стране, извесно није ни могао добити. Наравно да је и у овом случају, као уосталом и у случају Тешана Подруговића и Старца Милије, Вук имао разлога да жали што сусрет са њима није боље искористио, али једном пропуштена прилика ретко се када поново пружа, поготову у овако осетљивом послу као што је записивање народних песама.

Вишњићеве песме о Првом српском устанку, осим несумњиве уметничке вредности, поседују и изузетан документациони значај, како у погледу стварних збивања, тако и у погледу доживљавања савременика тих догађаја, посебно улоге и карактера непосредних учесника у њима. Песник опевава, али и веродостојно сведочи. Тражи разлоге за догађаје о којима је реч.

Уз све тешкоће, невоље и отпоре, које носи собом, робовање освајачу и његовој власти, народу, ипак, најтеже падају зулуми пустахија и одметника од те власти, па ма каква она сама по себи била. Она је, колико-толико, предвидива и врши се у неким оквирима, и по некаквим правилима. Самовољне пустахије не поштују ништа и препуштају се својим опаким нагонима и склоностима. Запамтила је таквих више наша народна песма: почев од силног Влах Алије, Арапа Прекоморца, Уса Арапина, па преко Мусе Кесеџије и Ђема Брђанина све до Вишњићевог времена и београдских дахија.

Ту свест најконкретније изражавају управо стихови из песме „Почетак буне против дахија“:

„Трчи Ђорђе од града до града

и грађане свагђе довикује:

'Чујете ли ви Турци грађани, 
на градов’ма отварајте врата, измеђ' себе дајте зулумћаре, ак' хоћете мирни да будете, да градове цару не кваримо; јер ако их ви дати нећете, те градове раја начинила, градила их по девет година, кадра их је за дан оборити и са царем кавгу заметнути и са царем кавгу заметнути“.

Због тих насилника и њиховог зулума који се излио мимо свих друштвених и моралних закона и обзира устанак је и плануо и једно време настојао тај домет и карактер и да задржи, макар и привидно. Такво мишљење о њему владало је и на ширем простору српскога народа. И не само српскога. Можда га је н најнепосредније изразио Петар Први Петровић Његош, митрополит Црне Горе и Брда у писму Карађорђу Петровићу, у коме, између осталог, каже: „Ја благодарим Бога који Вам је открио разум и даровао толики дух неустрашиве храбрости, да соједините сердца Ваша во једномислије, да се браните од самовољства непослушних Вашега честитога цара, који су Вас и Вашу браћу тирански на сваке начине мучили и угњетавали“. А онда, умни и искусни митрополит, познавајући људски род, а посебно своје најближе, упозорава: „Но, бојати се страшне человеческога рода непријатељнице зависти која је у нашим народим на несрећу свијех издревле (од давнина - Љ. 3.) обикла царствовати“.

Није, нажалост, требало дуго чекати ни у овој прилици да би митрополитово страховање и предвиђање показало своје злокобно лице. Већ пред бој на Чокешини сусрет устаничких првака Ћурчије и Ја- 
кова Ваљевца у истоименој Вишњићевој песми изгледа овако: „у образ се они пољубише, ал’ за здравље питат се не шћеше, веће одма кавгу заметнуше“. Ево и повода свађи и, нажалост, истовремено и узрока поразу:

„Вако рече Ћурч’ја арамбаша:

'Та Јакове, српски комендате,

Оћеш, болан, више довест војске?

Ако л' нећеш више довест војске,

Ја се први с Турци бити нећу,

Јер ја нисам дрво врбовина,

Кад посјеку да с’ омладит могу,

Па да будем врба ко и била,

Већ Ћурчија, горски арамбаша,

Кад пос'јеку, омладит се нећу'“.

Пошто још један устанички старешина и првак, Мијајло Ружичић, видећи како Ћурчија „бјежи уз планину“, одустаје од борбе са онима који свим силама кидишу на устанике и богату Мачву, и поред јуначког отпора оних који су неравноправну борбу ипак прихватили, пораз је био неминован. Изостало је оно за овакав подухват и најглавније - изостала је слога и јединство. Рекло би се да ту свак води неки свој приватни рат, у свом атару, чак дворишту. Тако Ружичић Мијајло, одустајући од борбе и пре него што је почела, својој војсци наређује: „Ви бјежите сваки своме двору, да се сваки код свог двора нађе“. Једна од добро уочених карактеристика сваке буне, према томе и Првог српског устанка; поготову у његовим првим данима и месецима.

А песник прижељкује, истиче и хвали нешто сасвим друго, чак супротно од онога о чему је овде било речи. Жели, дакле, слогу и јединство. Ту његову жељу снажно изражавају стихови којима приказује четворицу најистакну- 
тијих јунака у овоме боју. Они, без обзира на бројност и снагу противника, храбро прихватају бој и то, како они најсрчанији међу њима траже - „св’јету на видику“:

„...сва четири јесу једнолика,

једног раста,а једног погледа,

једне ћуди, а једне помисли“.

На њима је чак и „рухо једнолико“. Појединост која у свести слушалаца, односно читалаца, дозива онај призор из познате басне „Какве су длаке, онакве су и ћуди“. У њој је реч о обрачуну између вукова и паса.

Вишњић настоји да истакне врлине и јунаштво свима онима који смогну снаге да то, кад затреба, и покажу, а најбоље „ђе је св’јему свјету на видику“. На томе Вишњићеви јунаци више пута инсистирају. Али, ништа мање и да укаже на мане, себичност и малодушност оних који их испоље кад то народу највише штети. Тако, ни у овој песми неће прећутати да се Јаков Ваљевац уплашио, па једино: „иде виђет побит како ће се“, али у самом боју не учествује. На крају га једино видимо како на свом коњу бежи „стрампутицом путем пријекијем“. Песник се строго држи онога што је о догађају дознао и то се у народу прича.

Он је, према томе, основне слабости устаника, као и разлог тешком поразу у овом боју, видео у старешинама, зато њима, на више начина и у више прилика, и упућује замерке и оштре прекоре. Најпре сасвим отворено и непосредно, у песми „Почетак буне против дахија“ тврдњом да они баш и „нису ради кавзи“ с Турцима зулумћарима. Нешто мање отворено у примеру песме о којој је управо било речи, а најотвореније у песми „Бој на Салашу“ на уста оног стражарчета, слуге Јуришића Станка. Оно, задихано, огорчено и кроз сузе пита војводе: 
„Тко је вама коње набавио, тко је вама чоху порезао, тко ли вам је поково оружје разма јадна сиротиња раја?"

Па сад војводе, некако одвећ опуштено и готово безбрижно, пију вино и певају, док „сиротиња у невољи цвили“. Од њих се очекује нешто сасвим друго, да траже излаз из тешких прилика у којима се народ нашао, донекле и њиховом заслугом. Под жестином овога прекора некако ће се, у конкретној прилици, ипак, остварити јединство међу војводама којима су прекор и осуда најнепосредније и упућени. Зато:

„три војводе заједно пођоше, три војводе као три сокола, а за њима до двјеста Србина, као сродно јато голубова Боже мили, да лијепе ките!“

Радосно ће кликнути песник, али изостаје утисак да је то јединство постало и део свести устаника без чега не може бити ни успеха у борби коју су започели. Наравно, познаваоци тадашњих историјских и друштвених прилика казаће да то друкчије и није могло бити. То је вероватно тачно, те се ствари, јединство и свест о његовом значају за успех не постижу преконоћ. Песнику је, међутим, било битно нешто сасвим друго, да истакне важност слоге и јединства у сваком подухвату, утолико важнији уколико је подухват тежи и дугорочнији, а за цео народ од судбинског значаја. Тога је, наравно био свестан и Вишњићев савременик, уз све остало и творац епских песама о борбама племена чији је духовни и световни поглавар био већ помињани Пе- 
тар Први Петровић Његош, који ће у песми „У похвалу Карађорђу Петровићу“ ускликнути:

„Ето, брате, шта чини јединство,

кад једноме дају старјешинство,

и кад нема злога самовољства,

и на новце клетога лакомства!“

Тако су слози, које је Србима најчешће мањкало, готово истовремено, и истим поводом, кликтали Филип Вишњић и потоњи Свети Петар Цетињски.

Из Вишњићевих песама намеће се недвосмислен утисак, односно закључак, да је на делу једна много дубља, болнија и далекосежнија пукотина на бићу српског народа. Она се претвара у провалију. То је, наравно, она настала на верској основи. Зато књиге којим се окупља војска да казни бунтовну Србију и угуши устанак најчешће иду преко Дрине „на Бошњаке Турке мусломане“. Аутохтоних Турака и њихових потомака, вероватно је и у том тренутку мање међу Србима, него Срба и њихових потомака у Турској. Главни, према томе, противници устаника у Србији стизали су, углавном, из Босне. То су острвљене убице и пљачкаши који на богату Мачву и њене градове Шабац и Лозницу, „попријеко гледе“. Намере су им опаке и уопште их не крију већ жељно чекају згодну прилику да их остваре. Тако Кулин-капетан, највероватније потомак неког потурченог Србина, крећући с војском на Србију дрско прети: „Хоћу, море, Србе разредити, ви Кулина хоћете познати!“. Отуда, ваљда, и она наша народна изрека: ако немаш злотвора - мајка ти га је родила. На другој страни, „Бошњаци Турци мусломани“, како их песник назива, Србе виде као влахе, који „прелијећу преко воде Дрине те се наше Босне доваћају“. Ни у примисли 
им није оно што је Вишњић на уста вожда Карађорђа пожелео, да Дрина постане међа племенита измеђ Босне и измеђ Србије.

Вишњићеви јунаци су стално у вртлогу крвавих ратних догађаја, задихани и узбуђени, напрегнутих чула, нарочито они поред десне обале Дрине. Они са друге, леве обале вребају сваку згодну прилику да се загнају у пљачку, убијање и заробљавање. Жестоке борбе понекад трају данима. Па стога браниоци „Ни престаше, нити сна имаше, ни сједоше ни љеба једоше“. Но, и поред тога, песник стигне да им понекад загледа у душу, да каже о чему брину и како се осећају. А они брину и мисле и о томе како ће је, и поред свих искушења и неприлика, своју душу „врћи у чистоту“. Тако Богићевић Анто у највећој муци не жали „ми војводе што би изгинули, али шта ће наше јадне душе - душе наше неће виђет божјег лица“, прибојава се славни војсковођа. Брига за душу мучи и првог војника устанка, вожда Карађорђа. Његова је одговорност и највећа. Он је „први кавгу заметнуо“, према томе, и „црвописак на душу узео“, па сад га највише мори брига „куд ће моја, (то јест, његова) душа и тијело?“. Онај ко је рачунао и на милостињу слушалаца својих песама, а Вишњић је, извесно, био тај, није смео заборавити бригу за душу ни својих јунака, ни слушалаца својих песама. Ocећао је потребу да их на неки начин опомене и подсети на милосрђе. Да, бар понекад, помисле на награду која их чека на оном свету за несебичност и доброчинства, или казну за себичност, користољубље и друга непочинства. А најснажнији разлог, онај који се ни по цену живота не сме пренебрегнути, јунак има кад се у његовој души укрсте осећања грехоте и срамоте. Тако Стојан Чупић у песми „Бој на Салашу“, позивајући у помоћ Јанка и Вујицу, додаје: 
„Ил’ ви пошли, ил' не пошли, браћо,

Ја ћу један ударит на Турке,

Под срамотом овом остат нећу,

Мрет ми данас или мрети сјутра,

Волим прије о мање гријоте“.

Тим је духом прожета цела његова песма „Кнез Иван Кнежевић“. Иначе, ова песма, уз Вукову напомену којом је пропраћена, има, превасходно, документарну вредност. Има и моралну, свакако. Као пример да се злу и вероломству успешно можемо супротставити љубављу и доброчинством у песмама из овог круга, иначе, све варничи. Севају искошени погледи, пуни мржње и претње. Чује се шкрипа зуба. Српским се јунацима у судару с противником отме и понека груба псовка, ликовање пуно сарказма.

„Mope, Мехо, је л' ти мало пића?

Многога сам тако напојио,

Па кад заспи, више се не диже!“

Са задовољством се међу погинулим противницима помиње и хоџа, коме је са најнадлежнијег места било наложено „да по земљи благе р’јечи збори“. Не каже се, додуше, ни да ли их је зборио, ни да ли му је ко веровао. Вероватно је на делу био такозвани такијах, по Шеријату сасвим легитиман начин да се причом противник обмане, доведе у заблуду како би се лакше и уз мање сопствене напоре и губитке савладао. Занимљиво је то да је песник знао за њега и да га је поменуо.

Ратови, уколико нису искључиво одбрамбени, углавном се воде ради освајања туђих територија и, наравно, пљачке ради. Турска је држала да је све српске територије већ једном освојила и да их сад 
само ваља држати у покорности и запту. Повремене немире и буне, ако до њих дође, гушити, а бунџије сурово кажњавати. Што се тиче Првог српског устанка, који је започет као буна против дахија, он се настојао угушити, превасходно, уз помоћ исламизираног дела балканских Словена који је био лојалан Турској. Претежно се, опет, радило о превереним Србима. Те су војске, углавном, долазиле из Босне, где је процес исламизације у прошлости био и најснажнији. По правилу, те су казнене експедиције на Србију кретале са знањем и наређењем Порте, али, како су ти походи редовно имали пљачкашки карактер, поједини локални силници и острвљене кабадахије предузимали су их и на своју руку. Као се то у једној песми Вишњићевој и каже: „без фермана и без бурунтије и без р’јечи цара честитога“. За успешно завршен поход, вероватно се могла се очекивати награда, најмање похвала и признање од централне власти. Али се увек рачунало на пљачку житеља богате Мачве, у шта је спадало и одвођење робља, за које је после уцењивано високим откупом. О томе верно и упечатљиво сведочи песма „Кнез Иван Кнежевић“. Познато је да је турска војска кретала у јуриш на противника узвикујући: „Јагма, јагма!“. Било би одвећ наивно поверовати у то како су српски устаници од сличних појава и склоности били имуни. Јасно је да нису, али су се њихове позиције битно разликовале. Једно су, како би рекао Његош били хајдуци што гоне хајдуке, а друго су били хајдуци робла свезанога, које на све начине настоји да ce, најзад, тог тешког и дуготрајног ропства ослободи.

Ево доказа за то да су пљачка и грабеж сматрани и као додатни мотив за још жешћи јуриш на опасног и упорног противника који, у конкретном случају, данима опседа Лозницу. Након клетве, класичног начина обавезивања на борбу: 
„Ко издао, издало га љето,

Бијело му жито не родило,

Стара њега мајка не виђела,

Њим се мила сестра не заклела!“

Луко Лазаревић као да се побојао да то није довољан јемац за оно што жели да постигне, па зато нуди један поузданији:

„Јоште, браћо да вам ово кажем:

Који би што у боју добио,

Да добије везирово благо,

Нека другу не даде исета,

Проклет био ко од њег искао!

Свако себи нек шићара тражи.“

Разуме се, браниоци ће уграбити оно што нађу код убијених противника, а ови су без милости жарили и палили њихове претходно опљачкане домове и богомоље.

Од непосредне стварности и збивања „по земљи Србији“, загледавши се својим духовним очима у онострано, Вишњић се привидно највише удаљио кад се осмелио да покаже како, најпосле, да би покренули Србе на оружје, „небом свеци сташе војевати“. То се у нашим народним песмама, у таквом облику, јавља први и једини пут. Наравно да нас то војевање светаца у Вишњићевој песми у извесној мери подсећа на војевање олимпијских богова у Хомеровој Илијади. Но, она се међусобно и дубоко разликују. Вишњићеви свеци не војују непосредно као Хомерови богови, већ знацима, небеским приликама опомињу и позивају Србе на оружје, на отпор безакоњу и понижавању које траје вековима. Позивају на борбу за највеће људске вредности - слободу и живот достојан човека. Тројански рат, у који су умешани и олимпијски 
богови - они су га и изазвали - води се због лепе Хелене, жене спартанског краља Менелаја. Њу је, злоупотребивши гостопримство, уграбио тројански принц Парис. Наравно, уз помоћ сујетне богиње лепоте, Афродите. Била је то награда за што је између свих богиња њу прогласио најлепшом.

Отмицу жене, ма колико вредне и лепе, наша народна песма би сматрала довољним разлогом за двобој какав је, на пример, приказан у народној песми „Бановић Страхиња“, али, свакако не и за рат какав се због лепе Хелене води између Тројанаца и Ахејаца. У који би се још укључили свеци, односно богови. Још јачи разлог за сукоб, односно двобој, био би ако би дошла у питање заштита части жене, поготову девојке. А тиме, у исти мах, и част њеног мужа, односно брата. Имамо такав пример у песми „Болани Дојчин“, а сличан и у неким другим. Занимљиво је, свакако, да сукоб због жене, без обзира на њену лепоту, у нашој народној епици не спада у разлоге првога реда за свађу и обрачун међу јунацима. Опевано је, истина, неколико и таквих примера, али су они, по правилу, приписивани иноверцима. Тако се у једној песми, записаној од Тодора Икова Пипера приказује сукоб због девојке браће Муја и Алије, али се изричито наглашава да је разлог за сукоб недостојан јунака - избио је, како песма каже: „да око шта веће ни око шта, око једне поганске работе, око једне лијепе ђевојке“. Сукоб стога и доживљава осуду оних који су покушавали да измире браћу закрвљену око поганске работе, која, иначе, овде звучи готово као митонимијска ознака за жену уопште.

У сваком случају, сличност између деловања божанских сила у Вишњићевој песми „Почетак буне против дахија“ и Хомеровој Илијади само је на први поглед сличан. Рекло би се да је Вишњићево војевање светаца 
„виш Србије по небу ведроме“ само најмање упитан доказ за то колико је оружани отпор народа српскога злу и неправди био чин више правде и нужности. Али, с обзиром на број позива, односно прилика, и снажан прекор за оклевање и малодушност. А на крају и оно најбитније - охрабрење. Канда би то, ипак, све било недовољно да се, најзад, диљем земље Србије испод неба ведрога не закотрљаше главе српских кнезова, сматра песник поузданог осећања за реалност.

Острвљене и осионе београдске дахије, међутим, бејаху изгубиле сваки осећај за стварност, било какву обзирност и меру. Пред њиховом обести и самовољом се, једноставно, морала повући и мудрост и искуство старог Фоче, његов поуздани осећај за историјске и друштвене законитости и мене; човекову потребу, чак нужност, да им се прилагођава. Наравно, зна он добро, некада је било сасвим друкчије, али су се, стицајем околности, прилике промениле и сад захтевају друкчији начин размишљања и владања. Прихватања нове стварности опстанка ради. Једноставно, ради се о нужности изражена стихом: не би л' и ми уз них преживели. Како, уосталом и саветује искусни старац Фочо. Сила је, међутим, слепа и глува, или, како пева Радован Бећировић: „Власт човјека ставља изнад људи, од богатства може да полуди!“А дахије, тако им се бар чини, у том тренутку и једног и другог, и власти и богатства нарочито, имају у изобиљу.

Таква сагледавања прилика у Србији уочи Првог српског устанка, сликовито приказивање догађаја и њихових актера; проницањем у њихову душу, Вишњић се збиља високо винуо. Толико да је својом поезијом, пре свега песмом „Почетак буне против дахија“ најавио долазак највеће српског песника, Његоша, који му је у понечему, можда, и дужник. 
Вишњић је у више праваца направио снажне стваралачке искораке у односу на епско песничко наслеђе, које је, иначе, добро познавао и њиме се вешто користио, као општим добром, као језиком на коме је певао. Његов је десетерац гипкији и убрзанији у односу на традиционални. Лексика је знатно освежена новинама које се истичу и памте. Тако Турци не могу Карађорђа преварити, нити га могу спаваћива наћи. Не могу ни Штитарца, иако на све начине покушавају, посећи тежећва. Помишљам, како би се, аналогно овим изведеницама, могло казати и седећuв, па чак и стојећив, али тих израза нема у Вишњићевим песмама. Међутим, његови јунаци при сусрету руке не шире, као што је у народним песмама уобичајено, већ руке руче. Пушка Рада Прекодринца назалуд не пуца. Али-паша на „Бошњаке Турке мусломане“ шаље књигу клетвену. С тим у вези, казао бих да и употреба необичних синтаксичких облика, речи и њихових облика делимично може да буде последица захтева стиха, гусларског десетерца, посебно ако се песма казује певањем уз гусле. Према томе, делимично, у истом тренутку и спевава. Наравно да то важи и кад се песма само казује, с том разликом што се то тада ради мирније, с мање журбе. Зато се, чини ми се, на овом месту логично запитати: колико се Вишњић, казујући Вуку ове песме, њих присећао, а колико их је, у истом тренутку, стварао, макар понешто у њима мењао? Највероватније, на делу је било и једно и друго. Негде више једног, негде више другог. Пред Вуком се, сигурно, није осећао исто као пред свакодневним слушаоцима својих песама. Ови су само слушали, и понешто памтили, а Вук записује од речи до речи. То је за певача било нешто сасвим ново и морало је утицати на његово понашање. Оправдано је претпоставити да се својски трудио да песме испадну најбоље што је могуће. 
Снага песника Вишњића је, пре свега, у његовом снажном проницању у смисао и неминовност догађаја о којима пева. У поузданом осећању дотрајалости једне врсте друштвених односа и нужности њихове замене друкчијим односима; пре свега, положају актера у њима. Његова је снага у томе што је умео да ослушне и разабере шта се о свему томе прича, како се размишља о свему томе међу онима којих се све то и најнепосредније тиче, али, наравно, и колектива у целини у оба табора.

Из песама из овог круга све некако варничи. Севају искошени огледи пуни мржње и претње. Чује се и бесни шкргут зуба. При судару противника отме се чак и понека груба псовка. У тим жестоким обрачунима падају и они којима и звање и обавеза налажу „да по земљи благе р'јечи зборе“, чак и хоџа из Стамбола, који се, по свему судећи, уместо благих речи, био латио оштре сабље.

И са српске и са турске стране песник истури понеког јунака, а за њим ступа безлична маса. На једној страни су острвљени пљачкаши, пустахије и убице, а на другој сиротиња раја, кука и мотика која то више не може да мирно подноси, јер је толико страшно, неиздрживо - „У звери би срце пепукнуло, а камоли у живу јунаку“. За Србе је, према томе, овај рат мука и невоља, али се, одскора, и међу њима нађе и таквих јунака који имају снаге и срчаности и да се поиграју са противником. Такав је, примера ради, Милош Поцерац. Он једва чека да се судари са противником који је тако крволочно насрнуо:

„Браћо моја, пјешци и коњици, Ви хајдете како ви можете, А ја одох како ђогат хоһе: Ђогат ми је боја пожељео, Моја десна засилила рука, Рада се је с Турцима играти.“ 
Ово је, иначе, једна од лепших Вишњићевих песама из овога круга. Томе посебно доприноси што оружаном судару јунака претходи њихов резак обрачун речима, кога у сличном облику нећемо наћи ни у једној другој народној песми. У њему се помињу и противникове љубе и мајке да све то што они раде није само обесна игра, него и трагедија која се не тиче само њих.

Иначе, са изузетком Кулинове каде и, донекле Крсманове љубе, помињање жена је, мање-више, узгредно у поменута два случаја. Посебно у првом, жена је особа у чијој ће души најдубље и најболније одјекнути догађаји који се збивају на бојном пољу и свему томе дати једну посебну димензију готово трагичног да не би оног њеног лакомисленог, и на вересију, ликовања над туђом несрећом и понижењем. Песник, срећом, не ликује. Он само приказом догађаја показује да батина има два краја. И да се туђој несрећи не би требало радовати и у њој тражити своју срећу. У сваком случају, без Кулинове каде и њеног доживљаја опеваног догађаја, песма би се свела на пуко набрајање догађаја, учесника у њему, и ко је и од чије руке погинуо.

Е, у том проналажењу сличних димензија у опеваним догађајима и ликовима и видим Вишњићево песничко мајсторство. Да завири и у женско срце, да се вине у небо, да се смело отисне у прошлост, све до Косова, Мурата и Милоша, и на тај начин избегне сувопарно набрајање догађаја о којма је започео причу. Да им обезбеди један богатији и занимљивији оквир.

На крају кад се све сабере и подвуче, намеће се утисак да је у овим песмама главни јунак народ, сиротиња раја, кука и мотика. У њему је сва снага отпора и решеност да се за своја људска права бори до једнога. Прваци би требало да служе том народу, његовим жељама и потребама, а не својим сујетама и прохтевима. Наравно, Вишњић је узоран хришћанин и природ- 
но је да од јунака на чијој је страни и чије подвиге слави очекује да воде рачуна да се не огреше, пре свега, о сироте и беспомоћне.

Academician Ljubomir Zuković Academy of Sciences and Arts of the Republika Srpska, Banja Luka

\section{JUBILEE OF FILIP VIŠNJIĆ}

On the occasion of the two hundred and fifty years since the birth of Filip Višnjić, the author deals with the songs that Filip Višnjić sing alongside the gusle, while Vuk Karadžić recorded them from him. The author devotes attention to the poems that, according to Vuk's division, belong to the circle of songs of middle and elderly times. The subject of the authors' interest in the second part of the work is the poems about the First Serbian Uprising, which Višnjić himself conveyed, but in the means, and in the manner that the collective immediately accepted them as their own.

Key words: Vuk Stefanović Karadžić, Filip Višnjić, First Serbian Uprising. 